\title{
Analysis of Value-Added Tax Treatment of Unit Linked Life Insurance Services
}

\author{
Muhammad Ravin Alhakim ${ }^{1 *}$, Yohanes Yohanes ${ }^{1}$ \\ ${ }^{1}$ Faculty of Economics and Business, Universitas Indonesia, Depok 16424, Indonesia \\ ${ }^{*}$ Corresponding Author: quonrav@gmail.com
}

\begin{abstract}
Unit linked insurance companies have two activities, namely assurance services and investment management services. The purpose of this study is to analyze whether or not unit linked life insurance services are included in the terms of Taxable Services that impose Value Added Tax (VAT), and how the imposition and calculation of VAT are carried out on a Tax Imposition Basis (TIB). Based on a Tax Court Decision case study, there is a dispute as to whether or not unit linked life insurance services impose VAT. There is a difference of opinion between the Directorate General of Taxation (DGT) and insurance companies and judges. The method in this research is descriptive analysis in the form of a case study. Analysis of the VAT treatment of unit linked life insurance services is carried out by interviewing informants and through a study of the literature. The result is that all parties agree that the assurance service does not impose VAT, while there are different opinions concerning the investment management service. Analysis is also carried out on the calculation of the VAT on a TIB for unit linked investment management service as the replacement price based on the investment management fee charged to the customer and the top-up charge of the investment.
\end{abstract}

Keywords: Unit Link; Insurance; VAT; Investment Management Services.

\section{INTRODUCTION}

Insurance companies in Indonesia create insurance products in the form of unit linked products to attract the public to purchase insurance. A unit linked insurance plan is a product that combines protection and investment, but with a lower and stable return. In unit linked products, there are usually several charges to customers, including investment management fees that are deducted by the insurance company from the investment returns of its customers. These investment management fees form the revenue of unit linked investment management services for insurance companies.

In Law Number 8 of 1983 on Value Added Tax of Goods and Services and Tax of Luxury Good Sale as amended by Law Number 42 Year 2009, hereinafter referred to as VAT Law, insurance services are exempt from the imposition of VAT. The explanation in VAT Law states that insurance service means assurance services that include loss insurance, life insurance, and reinsurance companies to the policyholders. However, the explanation does not stipulate whether or not included services related to unit linked investment management services impose VAT.

From several Tax Court Decisions, there is a difference of opinion between the Directorate General of Taxation (hereinafter referred to as the DGT) and the Life Insurance Company (hereinafter referred to as Insurance Company). The DGT has reasoned that the insurance services that are exempt from the imposition of VAT are insurance premiums, while investment management services charged to customers are taxable services. The Insurance Company reasoned that Insurance Services should cover all services that are commonly provided by the insurance company, namely the insurance services and investment management services, and all services provided by the Insurance Company, which is an inseparable part of the insurance business, should be exempt from the imposition of VAT.

In fact, there have been differences in the Tax Court Decisions on this case, for example PUT.58189/PP/M.XIIIB/16/2014. Here the judge assumed that VAT would be imposed on the unit linked investment management service because investment management services do not include any transfer of risk from the insurance company to the policyholder. However, other Tax Court Decisions, e.g., PUT.53150/PP/M.IIB/16/2014, state otherwise, that VAT is not imposed on unit linked investment management services. The judge here considered unit linked to be the name of the life insurance product; there is thus unity on all investment management fees on unit linked insurance as an insurance product, with VAT not imposed on insurance products due to their status as a nontaxable service.

This difference of interpretation will absolutely create legal uncertainty. In the future, there will be a lot of tax dispute between the DGT and Insurance Company. The differences of opinion on the imposition of VAT for the 
above unit linked investment management services is a relevant issue for discussion. This discussion has focused on the causes of the differences in the perceptions of the Insurance Company and the DGT in interpreting existing regulations. In addition, the discussion has also focused on how the imposition of VAT and VAT on a TIB are to be calculated, if indeed VAT is payable on the unit linked life insurance service.

This paper is organized as follows. Section 2 comprises a literature review. Section 3 contains the research methodology. Section 4 contains the results of a discussion comparing the arguments from the informants and the calculation of the VAT imposition basis. Finally, our work in this paper is summarized in the last section.

\section{LITERATURE REVIEW}

Akula and Kanchu ${ }^{1}$, in a comparative study of traditional insurance and unit linked life insurance, found unit linked to be a life insurance solution that provides the benefits of protection and flexibility in investment. Compared to traditional policies, unit linked policies have risk factors. Policyholders can expect to receive good returns from unit linked over traditional policies, but the performance of unit linked products is highly influenced by market performance. The author did not examine the taxation aspect in unit linked plans ${ }^{1}$.

Jurado $^{2}$ compared life insurance taxation in ASEAN countries. He found that the imposition of VAT is not favored on life insurance among the ten member countries of the ASEAN. In Singapore, unit linked life policy and administration fees, which are incidental to the provision of a life policy contract, may also be exempt from VAT. On the other hand, long-term personal accident or medical insurance policies (which may be issued by a life insurance company) do not fall within the description of a 'life policy' in the Insurance Act, and such insurance policies do not therefore qualify for exemption from $\mathrm{VAT}^{2}$.

Kratimenos $^{3}$ analyzed how VAT exemption for insurance transactions provided by Art.135 (1) (a) RVD could be characterized as one of the "gray zones" of the VAT mechanism due to its lack of a sufficient definition. The author suggested that "the essentials of an insurance transaction are, as generally understood, that one party, the insurer, undertakes to indemnify another, the insured, against the risk of loss in consideration of the payment of a sum of money called a premium ${ }^{3}$."

In Indonesia, the imposition of VAT on unit linked products is not yet clearly regulated in VAT Law because a unit linked plan is a hybrid product between insurance and investment. Insurance services follow Article 4A paragraph (3) letter e and memory explanation of VAT Law. "Services of which are not imposed the Value Added Tax shall be certain services, 'insurance services'.” Insurance service means insurance services that include the loss insurance, life insurance, and reinsurance that is offered by an insurance company to its policyholders, excluding insurance support service such as that provided by an insurance agent, assessor of loss insurance, and insurance consultant. Insurance services are types of services that are not subject to VAT as they contain social and ethical elements, while supporting services of insurance are types of services subject to VAT $^{4}$. According to previous study, life insurance remains exempt from VAT for the reason that it is difficult to extract the value added from implicit margins related to the savings component of life insurance on a transactional basis ${ }^{5}$.

Unit linked investment management services, however, can be equated with the management of mutual funds subject to VAT, because VAT in Indonesia adheres to the principle of neutrality. The whole cost of the mutual funds is a 10 percent VAT object, since mutual fund management activities are not included in the Exempted Services of VAT in accordance with Article 4A paragraph (3) of the VAT Law ${ }^{4}$. Therefore, the Investment Manager must collect VAT on the costs charged to investors because they are taxable services.

According to previous study, life insurance contracts, including unit linked contracts, provide insurance against mortality-related risks. Life insurance contracts often extend over periods in excess of one year and may have an added savings component that is similar to a savings account or mutual fund ${ }^{6}$. If bank savings accounts and mutual funds are included within the VAT system, competitive neutrality requires that the savings component of life insurance be similarly taxed. The Tax Calculation Account System (TCA) can be extended to life insurance contracts by splitting the premiums between a pure insurance component and a savings component and performing separate TCA calculations for each component.

\section{RESEARCH METHOD}

The case of VAT disputes between the Insurance Company and the DGT is research of the type with a case study as the object of research. In this case study there are three examples of Tax Court Decision cases taken, namely:

a) Disputes between DGT and PT. AIA Financial (PUT.53150/PP/M.IIB/16/2014)

b) Disputes between DGT and PT XXX (PUT.55234 PP/M.IB/16/2014)

c) Disputes between DGT and PT Asuransi Jiwa Manulife Indonesia (PUT.58189/PP/M.XIIIB /16/2014).

This research has been conducted using a qualitative research approach. A qualitative approach focuses on a context that illustrates an understanding of the case under study; that is, the problems that arise in the treatment of 
VAT on unit linked insurance services between the DGT and Insurance Company. The issues of concern in this study will be described and analyzed in depth. Based on the results of the analysis, the researcher will conclude and provide suggestions to overcome the problems that arise.

The type of writing used is descriptive analytical by describing as closely as possible the data obtained in the research process and performing analysis and interpretation of the data leading to discourse and a conclusion by way of logical, theoretical, and practical thinking.

The data collection techniques employed are literature study and interview techniques. This study is conducted by searching and understanding literature sources in the form of books, journals, papers, articles, taxation provisions, and the financial statements of the insurance company and investment management company. This study is intended and directed to obtain a theoretical basis that will be used to analyze the problem of VAT imposition on unit linked insurance services. Field studies were conducted by collecting information through indepth interviews in order to obtain primary data. Interviews were conducted with the life insurance company, Indonesian Life Insurance Association, Financial Services Authority, the DGT and a taxation expert (VAT) on the imposition of VAT on unit linked insurance services.

The informants in this study were selected based on their competence, experience, and profession related to taxation and unit linked life insurance. The five informants who acted as a source of data in this study are given below:

a) Insurance Company; the interview was conducted with an informant from the tax division of the insurance company. This informant has experience in his work and follows the process of tax dispute on life insurance.

b) Indonesian Life Insurance Association (ILIA); the interview was conducted with an informant from the tax division who already knows the problems faced by the life insurance company related to the imposition of VAT.

c) Directorate General of Taxes (DGT); the interview was conducted in the Division of VAT Tax Regulation, related to their authority to make rules regarding the imposition of VAT on life insurance companies.

d) Tax Lecturer, who teaches VAT and other taxes in tax education and has 15 years' teaching experience

e) Tax Expert; the informant is a Value Added Tax expert, as well as an academic and practitioner. He has also authored books on VAT as a source of literature for academics and VAT practitioners.

The data analysis techniques used in this study are as follows: Analysis and description of the costs contained in unit linked life insurance based on interviews with the informants and review of Tax Court Decisions; analysis of the differences in opinion between life insurance company Indonesia and the DGT; interviews with the informants; and calculation of the imposition and VAT on a TIB on unit linked life insurance services.

\section{RESULTS AND DISCUSSIONS}

Based on a study of three Tax Court Decisions and interviews from the informants, there are several main reasons for differences in the opinions of the DGT and Insurance Company concerning the treatment of VAT imposition on unit linked life insurance services. These are as follows:

\section{Definitions of Insurance Services that Do Not Impose VAT}

According to the Insurance Company the definition of an insurance service that is not subject to VAT should include all services that are generally provided by an insurance company. This should include not only insurance premiums but also investment management services. While the DGT argues that insurance services (which are not subject to VAT) are merely insurance services, investment management services are not included in the definition. Likewise, the informant from ILIA said that until now there has been no clear VAT legal rule stating that services are not subject to VAT insurance premium only, while investment management services charged to policyholders are taxable services. The VAT Law does not stipulate that unit linked products are subject to VAT. On the contrary, the informant from the DGT explained that insurance services that are not subject to VAT are merely services related to insurance services, while investment management services are not covered services. The tax lecturer argued that, characteristically, insurance is a service of coverage. Insurance coverage services are not chargeable under the VAT Law. But the fact is that a unit linked product comprises an element of coverage and an element of investment. The investment element incurs investment management costs, which are subject to VAT, while tax experts argue that the premiums from insurance services that are collected by insurance companies are exempt from VAT, whereas the premium from investment management services is "by nature" not a form of insurance services; therefore, VAT is imposed.

\section{Unit Linked Products Are Life Insurance Products}

This difference occurs when the insurance company considers that the unit linked product constitutes life insurance. In order for life insurance not to be subject to VAT, this assertion is based on the explanatory memory of the VAT Law that life insurance is not subject to VAT. The ILIA informant stated that although unit linked products 
contain an investment component, the overall unit linked product remains an insurance product. Unit linked products are granted permission from the Insurance Regulator and do not require permission from the Capital Market Regulator. The DGT, however, considers a unit linked product to be a life insurance product associated with investments, whereby the company's investment transactions attract a management fee charged to the policyholder, and this transaction is separate from the insurance. The tax lecturer agrees with the DGT that unit linked insurance in addition to the promise of coverage also contains elements of investment. The tax expert explained that a unit linked product combines both insurance services and investment management services and that an investment in a unit linked product is merely aimed at customers who have more money.

\section{Unit Linked Investment Management Services}

Insurance companies assume that unit linked investment management services are not subject to VAT as a part or an entity as an insurance service that is not an object of VAT. While the DGT assumes that unit linked investment management services are subject to VAT, investment management services are not included in the definition of insurance and are additional activities beyond life insurance products. The tax expert agrees with the DGT that the investment management service in unit linked insurance is subject to VAT because it is not an integral part of the insurance service. While the tax lecturer suggested that although VAT is imposed on an investment management service, the DGT should establish a clear regulation on the imposition of VAT on investment management services.

\section{Investment Portfolio Owner}

The insurance company explained that the funds from premium unit linked insurance products together with traditional insurance premiums are placed in an investment portfolio owned by the Insurance Company, meaning that the portfolio owner is an insurance company. The DGT assumes that the investment product derived from a portion of the insurance premium is owned by the policyholder and that the Insurance Party manages only the policyholder's investment.

Table.1. Summary of Different Arguments from Informants

\begin{tabular}{|c|c|c|}
\hline No & Insurance Company, Indonesian Life Insurance Association & $\begin{array}{c}\text { Directorate General of Taxation, Lecturer in Taxation Field, and } \\
\text { Taxation Expert (VAT) }\end{array}$ \\
\hline 1 & $\begin{array}{l}\text { Definitions of Insurance Services that do not impose VAT } \\
\text { All services either as a service or investment management } \\
\text { services. } \\
\text { There is no clear VAT legal rule. }\end{array}$ & $\begin{array}{l}\text { Only insurance services, investment management services not } \\
\text { included in the definition. }\end{array}$ \\
\hline 2 & $\begin{array}{l}\text { Unit Linked Products are Life Insurance Products } \\
\text { Unit linked products are life insurance products and the } \\
\text { investment portion is separate as a life insurance product. }\end{array}$ & $\begin{array}{l}\text { The investment portion of a unit linked product is separate from } \\
\text { the insurance portion. }\end{array}$ \\
\hline 3 & $\begin{array}{l}\text { Unit Linked Investment Management Services } \\
\text { Not subject to VAT }\end{array}$ & Subject to VAT \\
\hline 4 & $\begin{array}{l}\text { Investment Portfolio Owner } \\
\text { Insurance company, funds paid by the customer are } \\
\text { recorded in the company's bookkeeping as premium } \\
\text { income of the company. }\end{array}$ & $\begin{array}{l}\text { Policyholder because it can be taken at any time without any } \\
\text { legal or contractual restrictions and Tax Law adheres to material } \\
\text { rather than formal principles. }\end{array}$ \\
\hline
\end{tabular}

Based on the analysis and interview described, VAT is not imposed on the insurance service but it is imposed on the investment management service. To determine the VAT on a TIB for the insurance company, it is necessary to separate in advance the elements of the costs contained in the unit linked life insurance.

Table.2. Elements of the Costs Contained in Unit Linked Life Insurance.

\begin{tabular}{clll}
\hline No & \multicolumn{1}{c}{ Cost Type } & \multicolumn{1}{c}{ Premium Portion } & Explanation \\
\hline 1 & Cost of insurance & Related to Insurance Service & Not Payable VAT \\
2 & Cost of rider & Related to Insurance Service \\
3 & Acquisition cost & Related to Insurance Service & Not Payable VAT \\
4 & Administration cost & Related to Insurance Service & Not Payable VAT \\
5 & Investment management charge & Related to Investment Management Service & Payable VAT \\
6 & Top-up acquisition cost & Related to Investment Management Service & Payable VAT \\
\hline
\end{tabular}

The portions of the premium related to insurance services are the cost of insurance, cost of rider, acquisition cost, and administration cost. Costs related to insurance services cannot be used on a TIB because the insurance 
service is a nontaxable service and includes the types of services on which VAT is not imposed.

The portion of the premium related to investment management services, such as investment management charge and top-up acquisition cost, can be used on a TIB because investment management services are classed as a taxable service or exclude the types of services on which no VAT is imposed.

VAT on a TIB for cost related to investment management service uses replacement value. Replacement refers to the value in the form of money, including all requested costs or costs that should be requested by the Insurance Company due to the delivery of the taxable service. For example;

a. Investment Management Services $=\mathrm{Rp} 500.000$

b. Premium Services Top-up $=$ Rp 100.000

So, the Replacement Value is Rp 600.000 (Rp 500.000 + Rp 100.000) and VAT is Rp 60.000 (10\% x Rp 600.000).

\section{CONCLUSION}

In unit linked life insurance, VAT is not payable on the insurance service element, while VAT is payable on the investment management service part.

The imposition of VAT on the investment management service part of a unit linked product is calculated using the replacement price, which consists of the investment management fee charged to the customer/policyholder and the top-up acquisition cost charged to the customer/policyholder while increasing the investment portion.

To further provide legal certainty, the DGT needs to propose a regulatory proposal in the form of a Government Regulation concerning the imposition of VAT on the investment management service element of unit linked products.

\section{REFERENCES}

[1] R Akula, T Kanchu. Growth of ULIP policies in life insurance sector - A comparative study of traditional and ULIP policies. Indian Journal of Commerce \& Management Studies, 2(2) (2011) 190-199.

[2] FJ Jurado. Comparative Taxation of Life and Non-Life Insurance in ASEAN Countries. NTRC Tax Research Journal, 27(1) (2015) 830.

[3] N Kratimenos. The Scope of the VAT Exemption Applicable to Insurance and Reinsurance Transactions, including Related Services Performed by Insurance Brokers and Insurance Agents. Thesis, Lund University (2013).

[4] U Sukardji. Pajak Pertambahan Nilai, Edisi Revisi 2015. Rajagrafindo Perkasa, Jakarta (2015).

[5] A Schenk, V Thuronyi, W Cui. Valued Added Tax: A Comparative Approach, $2^{\text {nd }}$ Edition. Cambridge University Press, New York (2015).

[6] PR Merrill. VAT Treatment of the Financial Sector. Working Paper, Tax Analysts (2011). 